\title{
Practice and Associated Factors of Health Professionals towards Citizens' Charter at Jimma University Medical Center
}

\author{
Mulugeta Hailu Rad ${ }^{1 *}$, Dejene Melese Handalo ${ }^{1}$, Tilahun Fufa Debela ${ }^{1}$,Yibeltal \\ Siraneh $^{1}$, Firehiwot Worku ${ }^{2}$, Elias Ali Yesuf ${ }^{1}$
}

\footnotetext{
OPEN ACCESS

Citation: Mulugeta Hailu Rad, Dejene Melese Handalo, Tilahun Fufa Debela,Yibeltal Siraneh, Firehiwot Worku, Elias Ali Yesuf. Practice and Associated Factors of Health Professionals towards Citizens' Charter at Jimma University Medical Center. Ethiop J Health Sci.2019;29(5):535

doi:http://dx.doi.org/

10.4314/ejhs.v29i5.2

Received: March 8, 2019

Accepted: June 30, 2019

Published: September 1, 2019

Copyright: (C) 2019 Mulugeta Hailu., et

al. This is an open access article distributed under the terms of the Creative Commons Attribution License, which permits unrestricted use, distribution, and reproduction in any medium, provided the original author and source are credited.

Funding:Jimma University funded this study

Competing Interests: The authors declare that this manuscript was approved by all authors in its form and that no competing interest exists.

Affiliation and Correspondence:

${ }^{1}$ Department of HealthPolicy and

Management, Faculty of Public

Health, Institute of Health, Jimma

University, Ethiopia

${ }^{2}$ St. Paul's Hospital Millennium

Medical College, School of Public

Health

*Email:mulu4915@gmail.com
}

\section{ABSTRACT}

BACKGROUND: Citizens' Charter is a public promise between citizens and service providing organizations which visibly specifies expectations and standards in the service delivery. Citizens' charter standard has been implemented in Jimma University Medical Center since 2016/17. However, the practice and associated factor of citizens' charter among health professionals have not been studied yet. Hence, the aim of this study was to assess the practice of citizens' charter and associated factors among health professionals.

METHODS: Facility based cross-sectional study was conducted on 389 health care providers, selected through stratified sampling, from April 1 to April 26. Data was collected using a pretested structured self-administered questionnaire. Data were entered into EPI-data version 3.1 and exported to Statistical Package for Social Sciences (SPSS) version 20. Descriptive statistics, binary and multivariable logistic regression analysis were done. P-values less than 0.05 were used to declare significant association between dependent and independent variables. In the process of multivariable logistic regression analysis, knowledge and attitude variables were not tested due to low number of respondents to those specific variables' measuring items. Hence, it was difficult to declare as a predictor at bivariate analysis.

RESULT: For this study, the response rate was 92\%. Out of all, 237(60.9\%) professionals were properly practicing citizens' charter standard while 152(39.1\%) were not properly practicing it. The factors affecting the practice were job satisfaction [AOR $=7.4$, 95\% CI $(4.4,12.5)]$, perceived workload [AOR $=1.8,95 \% C I(1.05$, $3.0)]$ and type of profession $[A O R=5.4,95 \% C I((1.98,14.8)]$.

CONCLUSION: This study revealed that more than half of the respondents properly practiced citizens' charter. However, few health professionals only knew the existence of citizens' charter. Job satisfaction, perceived workload, and type of profession were the factors affecting the practice of citizens' charter.

KEYWORDS: citizens' charter, implementation, Jimma University Medical center 


\section{INTRODUCTION}

Citizens' charter is public a promise between citizens and service providing organizations which clearly specifies expectations and standards in the service delivery. It was first introduced by the United Kingdom in 1991 anticipating to empower citizens by informing their rights, privileges and responsibilities, and to make the administrative flexible. Since then, it has become one of the highlights of the wide spreading global reforms in public service delivery, adopted by many countries around the globe as an initiative $(1,2)$. Providing public services within a specific time limit, and decentralized and respectful way of delivery have been one of the main problems occurring in government organizations $(3,4)$.

A study conducted in Nepal on implementation of citizens' charter concluded that $46 \%$ of them clearly knew citizens' charter and $26 \%$ were not fully aware about citizens' charter in their offices (5).

A study conducted in Bangladesh concluded that $8 \%$ respondents among officials said that they were practicing citizens' charter without knowing its availability in their offices(6). A study conducted in a Kenyan hospital on the implementation of citizens' charter found that the awareness of care providers on citizens' charter was high. However, many of the participants were not certain that time frames in the citizens' charter were realistic (1).

A study conducted in Ghana hospital showed that $75 \%$ of health workers perceived that medium workload assignment would increase their performance (7).

Job satisfaction is one of the most important factors in increasing the employees' performance. It is known that less satisfied employees would not perform effectively in the workplace(8).

It is indicated that the implementation of the civil service reforms in Ethiopia has challenged by lack of appropriately combined and progressive method, inconsistency in performance evaluation system and civil servants' resistance to change $(9,10)$. A study conducted in Oromia Regional Bureau in Ethiopia assessed the implementation of citizens' charter found that only $38 \%$ of the respondent employees had full knowledge about citizens' charter of their offices (11).

Jimma University developed and implemented citizens' charter to provide more responsive and citizen-friendly service. The charter has been implemented in Jimma University Medical Center (JUMC) since 2017, where the public bodies have been able to improve their functioning over the years by referring to the principles and timeliness valued through these charters, thus promoting good governance, and greater satisfaction of the citizens in general (12).

As citizens' charter is newly launched reform initiative, many factors may affect its implementation. Little was known about the practice of citizens' charter standard and the factors influencing the practice of citizens' charter at Jimma University Medical Center. Therefore, the aim of this study was to address the practice of citizens' charter and associated factors among health professionals at Jimma University Medical Center, Southwest Ethiopia.

\section{METHODS AND PARTICIPANTS}

Study setting and design: The study was a facility-based cross-sectional design conducted at Jimma University Medical Center (JUMC), Southwest Ethiopia, located at 352 kilometers from Addis Ababa. The study was conducted from April 1, 2018 to April 26, 2018.

Randomly selected health professionals who worked in JUMC for three or more months were included in the study.

Sample size and sampling technique: Sample size was determined using single proportion population formula at $95 \%$ confidence level, assuming 50\% Health professionals practice of citizens' charter, and 5\% type I error. The required sample size with a $10 \%$ non-response rate was 423. First, study subjects were stratified according to their professional category. Then, the sample size was proportionally allocated for each professional category. Using the hospital's database for sampling frame, the study subjects were selected from each professional category using simple random sampling technique.

Study variables and measurement: Knowledge was measured with seven items; if respondents scored $60 \%$ and more categorized as

DOI: http://dx.doi.org/10.4314/ejhs.v29i5.2 
knowledgeable otherwise not knowledgeable. Attitude was measured with six items on five point likert scale ranging from 1 (strongly disagree) to 5 (strongly agree), and mean score was calculated. If respondents score mean and more they were categorized as having favorable attitude.

Practice: In this study, there were seven items with five point scale with options: never, rarely, sometimes, very often, always (with minimum score 7 and maximum score of 35). If respondents scored $80 \%$ (28) and more for the given practice questions, they were categorized as proper practicing; otherwise, they were designated as improperly practicing the citizens' charter.

Data collection: Data was collected by using selfadministered questionnaire which was adapted from different literatures. Knowledge was assessed by seven multiple choice and 'yes' or 'no' questions, attitude by six questions on five point Likert scale with 'strongly disagree' (1) to 'strongly agree' (5) and seven practice questions were used on five point scale ranging from 'not at all' (1) to 'yes always' (5). Data on socioeconomic and professional characteristics, perceived workload and overall job satisfaction were collected from health professionals.

Four BSc nurses from out of the study area were selected based on their experience and trained. They collected data from different working unit (medical, surgical, pediatrics, gynecology obstetrics wards and different outpatient departments); supervision was held by two MPH in health system management holders. Data was collected from April 1, 2018 to April 26, 2018 G.C.The tool was pretested on $5 \%$ (21) of total sample size at Shenene Gibe Hospital which is located out of the study area, and based on findings the tool were modified accordingly.

Data processing and analysis: Checking, coding and organization of the collected questionnaires were done manually every day to check for completeness. The completed questionnaires were coded, and data were entered into a data entry template in EPI-data version 3.1. After checking and correcting errors, the data were exported to Statistical Package for Social Science (SPSS) version 20. The negatively worded items were reverse-coded. Reliability of variables within each part was assessed, and variables with Cronbach alpha of 0.6 and more were included.

In the descriptive statistical analysis, frequencies, proportion and mean were calculated and the results of the analysis were presented in texts, tables and graphs as appropriate. Independent variables having $\mathrm{P}<0.25$ on binary logistic regression analysis were considered as candidates for multiple logistic regression analysis.

Multiple logistic regression analysis was carried out to identify factors having statistically significant associations with practice of citizens' charter service standard. The final model was fitted using backward LR variable selection methods. In the process of multivariable logistic regression analysis, knowledge and attitude variables were not tested due to small number of respondents to those specific variables measuring items. Hence, it was difficult to declare as a predictor at bivariate analysis. Significant independent predictors were declared at $\mathrm{p}$-value less than 0.05, and AOR was used for interpretation

Ethical issues: Ethical clearance was obtained from the Institutional Review Board of Jimma University, Institute of Health. Letter of cooperation was obtained from Jimma University Medical Center and the Academic Director. Participants were informed about the objectives of the study, and informed consent for participation was obtained from individual participants. Finally, participants were informed that they had full right not to participate in the study.

\section{RESULTS}

Socio-demographic characteristics: From the total eligible sample size of 423 healthcare providers, 389 participated in the study, which yielded a response rate of about $92 \%$. Two hundred twenty-seven $(58.4 \%)$ of the respondents were males. The age of the respondents ranged from 20-53 years with mean age of 28 (Standard Deviation $=4.5$ ) years. Two hundred twenty-five $(57.8 \%)$ of the respondents were single. Regarding the religion of the respondents, 169(43.4\%) were orthodox Christians followed by

DOI: http://dx.doi.org/10.4314/ejhs.v29i5.2 
protestants, 105(27\%), and Muslims, 95(24.4\%) (Table1). The average work experience of respondents ranged from $0.33-35$ years with mean experience of $4.15 \pm 3.3$ years. One hundred ninety two $(49 \%)$ had $2-5$ years and $22 \%$ had $>5$ years. The majority of the respondents were nurses, 234(60\%); other professional categories were less than $10 \%$ each.

Table 1: Socio-demographic characteristics of respondents Jimma University Medical Center, 2018(n =389)

\begin{tabular}{llll}
\hline Variables & & Frequency & Percent \\
\hline Sex & Male & 227 & 58.4 \\
Age & Female & 162 & 41.6 \\
Category & $20-25$ & 112 & 28.8 \\
& $26-30$ & 214 & 55.0 \\
& $31-35$ & 36 & 9.3 \\
Marital & $36-40$ & 20 & 5.1 \\
status & $>40$ & 7 & 1.8 \\
& Single & 225 & 57.8 \\
& Married or cohabiting & 155 & 39.8 \\
Religion & Widowed & 1 & .3 \\
& Divorced & 5 & 1.3 \\
& Orthodox & 169 & 43.4 \\
& Catholic & 10 & 2.6 \\
& Protestant & 105 & 27.0 \\
& Muslim & 95 & 24.4 \\
& Other(wakefata, don't have any & 9 & 2.3 \\
\hline
\end{tabular}

Work-related factors: Overall job satisfaction of healthcare providers: From total respondents $212(55.5 \%)$ were not satisfied with their Job (Figure1). Health professionals were asked does about their income, reflection of their work. Accordingly, $102(26 \%)$ respondents strongly disagreed, 109(28\%) disagreed and $79(20 \%)$ were uncertain on this statement. i.e. the majority of the respondents disagreed on their income related to their job.

Perceived workload: From the total respondents, 232(59.6\%) had high perceived workload while $157(40.4 \%)$ had medium workloads. Regarding training or orientation on citizens' charter, only 21 respondents got training or orientation. Out of 389 respondents, $129(33 \%)$ participated in healthcare quality improvement training for health professionals.

\section{Overall job satisfaction}

Among 389 respondents 212(54.4\%) were not satisfied with their job.

Knowledge of citizens' charter among health professionals: From the study respondents, only $25(6.4 \%)$ knew the existence of citizens' charter. Of those who had awareness on citizens' charter, 12(3.1\%) had adequate knowledge (Table 2). Regarding each knowledge question, out of 25 respondents, 20 did not know citizens' charter they year when citizens' charter started. However, 20 respondents correctly answered that citizens' charter states that special attention should be given to vulnerable groups (Figure1).

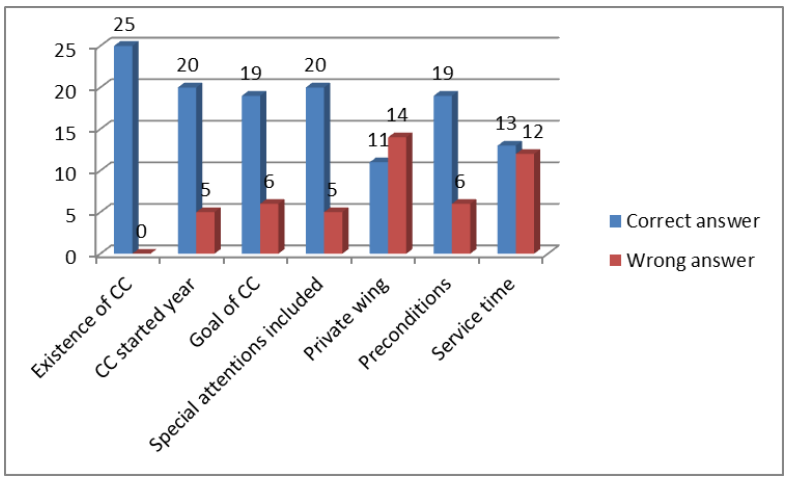

Figure 1: Response from respondents for each knowledge questions Jimma University Medical center, Southwest Ethiopia. 2018(n=389)

Health care providers attitude towards citizens' charter: Out of 25 respondents who responded to attitude questions, $11(2.8 \%)$ had favorable attitude while 14 had unfavorable attitude (Table 2). Regarding each item of attitude, respondents were asked if they believed that citizens' charter is useful in service provision. The response for this question was $6(1.5 \%)$

DOI: http://dx.doi.org/10.4314/ejhs.v29i5.2 
agreed and 15(3.9\%) strongly agreed. However, they did not agree that the time frame in the citizens' charter is doable; $9(2.3 \%)$ strongly disagreed while $12(3.1 \%)$ disagreed (Table 3).

Table 2: Status of knowledge, attitude and practice of health professionals at Jimma University Medical Center, Southwest Ethiopia $(\mathrm{n}=389)$

\begin{tabular}{lll}
\hline variables & Count & Percent \\
\hline Knowledgeable vs. & 12 & 3.1 \\
Not knowledgeable & 377 & 96.9 \\
Favorable attitude vs. & 11 & 2.8 \\
unfavorable attitude & 14 & 3.8 \\
Properly practicing vs. & 237 & 60.1 \\
improperly practicing & 152 & 30.9 \\
\hline
\end{tabular}

Table 3: Health professional's attitude towards citizens' charter of Jimma University Medical Center, Southwest Ethiopia. 2018(n=389)

\begin{tabular}{|c|c|c|c|c|c|c|}
\hline No & Items measuring PC & $\begin{array}{l}\text { Strongly } \\
\text { disagree }\end{array}$ & Disagree & Neutral & Agree & $\begin{array}{l}\text { Strongly } \\
\text { agree }\end{array}$ \\
\hline 1. & $\begin{array}{l}\text { Citizens' charter is useful in service } \\
\text { provision }\end{array}$ & 0 & $1(0.3 \%)$ & $3(0.8 \%)$ & $6(1.5 \%)$ & $15(3.9 \%)$ \\
\hline 2. & $\begin{array}{l}\text { Citizens' charter is useful in service } \\
\text { provision doesn't improves inquiry by } \\
\text { clients }{ }^{\circledR}\end{array}$ & $1(0.3 \%)$ & 0 & $7(1.8 \%)$ & $13(3.3 \%)$ & $4(1 \%)$ \\
\hline 3. & $\begin{array}{l}\text { Citizens' charter is useful in service } \\
\text { provision doesn't show reality in service } \\
\text { time standard } \AA\end{array}$ & $9(2.3 \%)$ & $12(3.1 \%)$ & $3(0.8 \%)$ & $1(0.3 \%)$ & 0 \\
\hline 4. & $\begin{array}{l}\text { I'm satisfied with the overall contents of } \\
\text { JUMC citizens' charter }\end{array}$ & $3(0.8 \%)$ & $2(0.5 \%)$ & $9(2.2 \%)$ & $3(0.8 \%)$ & $8(2.1 \%)$ \\
\hline 5. & $\begin{array}{l}\text { Citizens' charter is useful in service } \\
\text { provisionenhance productivity of } \\
\text { employee's productivity }\end{array}$ & 0 & $2(0.5 \%)$ & $7(1.8 \%)$ & $10(2.6 \%)$ & $6(1.5 \%)$ \\
\hline 6 & $\begin{array}{l}\text { Citizens' charter is useful in service } \\
\text { provision establish better complaints } \\
\text { handling system }\end{array}$ & $1(0.3 \%)$ & $1(0.3 \%)$ & $7(1.8 \%)$ & $10(2.6 \%)$ & $6(1.5 \%)$ \\
\hline
\end{tabular}

Practice of citizens' charter standard among health care providers: From the total study respondents, $237(60.9 \%)$ were properly practicing the contents of citizens' charter standard while $152(39.1 \%)$ were not properly practicing them (Table 2). Improper practice of citizens' charter was higher at the ophthalmology unit; al the 10 respondents were improperly practicing citizens' charter. Only 183(47\%) were always giving service at service time standard. Out the total respondents, 160(41\%) always gave special attention to disable patients, elders and other vulnerable groups (Table 4).

Table 4: Practice of citizens' charter of health care providers working in Jimma University Medical Center, Southwest Ethiopia. 2018(n=389)

DOI: http://dx.doi.org/10.4314/ejhs.v29i5.2 


\begin{tabular}{|c|c|c|c|c|c|}
\hline Items measuring practice & $\begin{array}{l}1 \\
\text { Not at all }\end{array}$ & $\begin{array}{l}2 \\
\text { Rarely }\end{array}$ & $\begin{array}{l}3 \\
\text { Few times }\end{array}$ & $\begin{array}{l}4 \\
\text { Some times }\end{array}$ & $\begin{array}{l}5 \\
\text { Yes always } \\
\end{array}$ \\
\hline $\begin{array}{l}\text { Do you give service for clients as specified } \\
\text { in service time standard } \AA\end{array}$ & $\begin{array}{l}14 \\
(3.6 \%)\end{array}$ & $\begin{array}{l}14 \\
(3.6 \%)\end{array}$ & $\begin{array}{l}56 \\
(14.4 \%)\end{array}$ & $\begin{array}{l}122 \\
(31.4 \%)\end{array}$ & $\begin{array}{l}183 \\
(47 \%)\end{array}$ \\
\hline $\begin{array}{l}\text { Do you encourage your colleagues to } \\
\text { provide according to service time standard } \\
\text { ( })\end{array}$ & $\begin{array}{l}18 \\
(4.6 \%)\end{array}$ & $\begin{array}{l}49 \\
(12.6 \%)\end{array}$ & $\begin{array}{l}87 \\
(22.4 \%)\end{array}$ & $\begin{array}{l}141 \\
(36.2 \%)\end{array}$ & $\begin{array}{l}94 \\
(24.2 \%)\end{array}$ \\
\hline $\begin{array}{l}\text { Do you give service with humbleness and } \\
\text { fairness }{ }^{\circledR}\end{array}$ & $\begin{array}{l}15 \\
(3.9 \%)\end{array}$ & $\begin{array}{l}18 \\
(4.6 \%)\end{array}$ & $\begin{array}{l}44 \\
(11.3 \%)\end{array}$ & $\begin{array}{l}135 \\
(34.7 \%)\end{array}$ & $\begin{array}{l}177 \\
(45.5 \%)\end{array}$ \\
\hline $\begin{array}{l}\text { Do you give all necessary and recent } \\
\text { information for your patients/clients } \AA\end{array}$ & $\begin{array}{l}8 \\
(2.1 \%)\end{array}$ & $\begin{array}{l}20 \\
(5.1 \%)\end{array}$ & $\begin{array}{l}72 \\
(18.5 \%)\end{array}$ & $\begin{array}{l}148 \\
(38 \%)\end{array}$ & $\begin{array}{l}141 \\
(36.2 \%)\end{array}$ \\
\hline $\begin{array}{l}\text { Do you encourage clients to go to next step } \\
\text { who have compliant about any } \\
\text { inconvenience }{ }^{\circledR}\end{array}$ & $\begin{array}{l}12 \\
(3.1 \%)\end{array}$ & $\begin{array}{l}36 \\
(9.3 \%)\end{array}$ & $\begin{array}{l}91 \\
(23.4 \%)\end{array}$ & $\begin{array}{l}129 \\
(33.2 \%)\end{array}$ & $(31.1 \%)$ \\
\hline $\begin{array}{l}\text { Do you give special attention for disables, } \\
\text { elders and other vulnerable groups }{ }^{\circledR}\end{array}$ & $\begin{array}{l}11 \\
(2.8 \%)\end{array}$ & $\begin{array}{l}9 \\
(2.3 \%)\end{array}$ & $\begin{array}{l}61 \\
(15.7 \%)\end{array}$ & $\begin{array}{l}148 \\
(38 \%)\end{array}$ & $\begin{array}{l}160 \\
(41.1 \%)\end{array}$ \\
\hline $\begin{array}{l}\text { Do you help clients to understand and } \\
\text { exercise their rights and responsibilities }{ }^{\circledR}\end{array}$ & $\begin{array}{l}13 \\
(3.3 \%)\end{array}$ & $\begin{array}{l}21 \\
(5.4 \%)\end{array}$ & $\begin{array}{l}62 \\
(15.9 \%)\end{array}$ & $\begin{array}{l}160 \\
(41.1 \%)\end{array}$ & $\begin{array}{l}133 \\
(34.2 \%)\end{array}$ \\
\hline
\end{tabular}

$(\mathbb{B}=$ reversely coded

Factors significantly associated with practice of citizens' charter: Type of profession, overall job satisfaction and perceived workload were significantly associated with practice of citizens' charter standard. Improper practice of citizens' charter was 7 times more likely to occur among unsatisfied participants compared with satisfied respondents $[\mathrm{AOR}=7.4,95 \% \mathrm{CI}(4.4,12.5)]$. Regarding type of profession, improper practice of citizens' charter was 5 times more likely to occur among nurses and midwives compared with other categories (anesthesia, mental health and radiology), but there were no differences among other professional categories $[\mathrm{AOR}=5.4,95 \% \mathrm{CI}$ $(1.98,14.8)]$. Improper practice of citizens' charter was 2 times more likely to occur among health professionals with high perceived workload compared with medium perceived workload [AOR $=1.8,95 \% \mathrm{CI}(1.05,3.0)]$ (Table 5).

Table 5: Independent predictors of practice of citizens' charter among health professional's Jimma University Medical Center, Southwest Ethiopia $(\mathrm{n}=389)$ (multiple logistic regression analysis)

\begin{tabular}{|c|c|c|c|c|c|c|}
\hline \multirow{2}{*}{\multicolumn{2}{|c|}{ Professional category }} & \multicolumn{2}{|c|}{$\begin{array}{l}\text { status of citizens' charter } \\
\text { practice }\end{array}$} & \multirow[t]{2}{*}{ COR $(95 \% \mathrm{CI})$} & \multirow[t]{2}{*}{$\mathrm{AOR} \& \mathrm{CI}$} & \multirow[t]{2}{*}{$\begin{array}{l}\mathrm{p}- \\
\text { value }\end{array}$} \\
\hline & & $\begin{array}{l}\text { Proper } \\
\text { practice } \\
\text { Count }\end{array}$ & $\begin{array}{l}\text { Not Proper } \\
\text { practice } \\
\text { count }\end{array}$ & & & \\
\hline \multicolumn{2}{|c|}{ Physician(specialist, GP and R1-R4) } & 44 & 17 & $1.28(.4,3.75)$ & $2.7(0.8,8.7)$ & 0.08 \\
\hline \multicolumn{2}{|c|}{ Nurse and midwife } & 140 & 123 & $2.9(1.14,7.5)$ & $5.4(1.98,14.8)$ & $0.001 *$ \\
\hline \multicolumn{2}{|c|}{ Lab tech and technologist } & 21 & 1 & $0.16(.01,1.4)$ & $0.2(0.02,1.89)$ & 0.16 \\
\hline \multicolumn{2}{|c|}{ Pharmacist and druggist } & 12 & 5 & $1.4(0.34,55)$ & $2.0(0.4,8.9)$ & 0.34 \\
\hline \multicolumn{2}{|c|}{$\begin{array}{l}\text { Others(anesthesia, mental health and } \\
\text { radiology) }\end{array}$} & 20 & 6 & 1 & 1 & 0.001 \\
\hline \multirow[t]{3}{*}{ Perceived work load } & High & 121 & 111 & $2.59(1.67,4.02)$ & $1.8(1.05,3.0)$ & $0.02 *$ \\
\hline & medium & 116 & 41 & 1 & 1 & \\
\hline & Satisfied & 148 & 29 & 1 & 1 & \\
\hline satisfaction & Not satisfied & 89 & 123 & $7.05(4.35,11.42)$ & $7.4(4.4,12.5)$ & $0.001 *$ \\
\hline
\end{tabular}

$\mathrm{COR} \& \mathrm{AOR}=1$ indicates reference group, ${ }^{*}=$ significant at $\mathrm{p}$ - value less than $5 \%$. Hosmer and Lemeshow Test model adequacy p-value 0.87 , overall percentage classification table $=75.6 \%$ and Nagelkerke R Square $=35 \%$ DISCUSSION It was found that from the total respondents, $237(60.9 \%)$ were properly practicing citizens'

DOI: http://dx.doi.org/10.4314/ejhs.v29i5.2 
charter while $152(39.1 \%)$ were not properly practicing it. From the respondents, 6.4\% knew the existence of citizens' charter and out this, $3.1 \%$ had adequate knowledge. It was found that $3.3 \%$ of the respondents who knew the existence of citizens' charter were properly practicing, and $57 \%$ were properly practicing without knowing existence of citizens' charter. This might be due to they are serving the community by their profession and the contents included in the citizens' charter are similar with their daily activities. portion of knowledge was smaller compared with a study conducted in Bangladesh among officials of whom only $20 \%$ knew the existence of citizens' charter (13). It was also much smaller compared with study a conducted in Ethiopia, Oromia Regional Bureaus, in which the majority of employees had awareness on the existence of citizens' charter in their bureau. Regarding their level of knowledge, $38 \%$ of the participants had detailed knowledge on citizens' charter of their bureaus (11). This might be due to differences in the duration of implementation. The former one was implemented in 2013, studied in 2017 while the later one was implemented in 2012 and studied in 2016. Both studies were conducted after four years of implementation.

From those who responded to attitude questions majority of respondents strongly agreed that the citizens' charter is useful in service provision. Respondents were asked if they believed that citizens' charter is useful in service provision. The response to this question were $6(1.5 \%)$ agreed and $15(3.9 \%)$ strongly agreed. However, 9(2.3\%) strongly disagreed and $12(3.1 \%)$ disagreed on time frames stated in the citizens' charter is practicable. This was similar with a case study of Kisii Level 5 Hospital in Kenya which found that service providers believed that the time frames stated in citizens' charter were not realistic (1).

This study revealed that Job satisfaction of healthcare providers greatly affected the practice of citizens' charter standard. Not satisfied health professionals were 7 times more likely to improperly practice citizens' charter compared with satisfied respondents. Eighty-five (22\%) disagree, $73(18.8 \%)$ undecided on their job has more advantage than disadvantage. Providers were asked does their income a reflection of the work they do; $102(26 \%)$ respondents strongly disagreed, $109(28 \%)$ disagreed and $79(20 \%)$ undecided on this statement. This finding is inline with job satisfaction of service providers has an impact on the satisfaction and quality care of patients (8).

This study showed that out of 389 respondents, $59.6 \%$ perceived high workload and $40.4 \%$ perceived medium workload. Health professionals with high perceived workload were 2 times more likely to improperly practice citizens' charter compared with those with medium perceived workload. This finding resembles a study done in a Ghana hospital on the effect of perceived workload on staff performance which showed that the majority of health workers perceived that medium workload assignment would increase their performance (7).

Professional category was found to be another significant factor affecting practice of citizens' charter standard. Nurses and midwives had higher probability of improper practice of citizens' charter standard compared with other (anesthesia, mental health and radiology) groups, but there was no difference among the other groups. This variation might be due to deference in professional commitment among healthcare workers.

Regarding training or orientation on citizens' charter standard, only $21(5 \%)$ got training or orientation, and out of 21,15 were properly practicing it. The proportion of training was similar with the study conducted by Fekadu Nigussa; in many cases the concerned staff were not adequately trained and sensitized; this was one of the major obstacles for the implementation of citizens' charter (10).

In conclusion, this study found that the majority of the respondents were properly practicing citizens' charter standard without information about its existence. However, there were many respondents who improperly practiced it. This study found that most of the 
respondents did not get training or orientation on citizens' charter. Few professionals had awareness about the existence of citizens' charter, and few of them knew in detail about the contents of the citizens' charter. This reveals that the charter was not rooted in the thought of all health service providers. Even those who knew the existence citizens' charter did not believe that the time standard stated in it is doable. Overall job satisfaction was the strongest predictor of practice of citizens' charter standard. Some professional categories and perceived workload were also significantly associated with practice of citizens' charter. One of the limitations of this study might be information bias (the information obtained was dependent on the respondents' self-report or perception).

The authors recommend that Jimma University Medical Center should discuss the time stated in the service standards with healthcare providers. Training or orientation should be offered to all healthcare providers on implementation of the charter. Motivating health professionals with incentives and promotion or personal growth is another area which should be considered in order to provide better responsive service to the clients/patients. Other researchers are encouraged to conduct further investigation including the patients' 'clients' perspectives.

\section{ACKNOWLEDGEMENT}

Our special thanks goes to data collectors, supervisors, study participants and Jimma University Medical Center. We would also like to thank Jimma University mega project funding program.

\section{REFERENCES}

1. Mang'era JO, Walter OB. challenges facing the implementation of citizen's charter a case study of kisii level 5 hospital - kenya josiah. interdiscip j contemp res bus. 2013;4:242-60.

2. World Bank. HOW-TO NOTES Citizen Charters : Enhancing Service Delivery Through
Accountability. 2003;1-17.

3. Chandra A, Bhatia S. The Right of Citizens for Time Bound Delivery of Goods and Services and Redressal of their Grievances Origin, Need , and Analysis Amit Chandra and Surbhi Bhatia Centre for Civil Society. Cent Civ Soc. 2015.

4. ECA. Public Sector Management Reforms in Africa. Igarss. 2014. 2014;(1):1-5.

5. Dhakal T., C.K G. Century has witnessed a fundamentally change in administrative values and the pattern of governing system. The New Public Management (NPM) doctrine came to replace the rigidity in the performance of government which features with outmoded rules and. 2009.

6. Rab A. Challenges and Prospects of Implementing Citizen Charter: A Study of Union Parishad in Bangladesh. 2017;7(3):1.

7. Asamani JA, Amertil NP, Chebere M. No Title. 2015;12968.

8. Talasaz ZH, Saadoldin SN, Shakeri MT. The Relationship between Job Satisfaction and Job Performance among Midwives Working in Healthcare Centers of Mashhad , Iran. 2014

9. Abera AM. The Impact of Citizen Charters to Establish Transparent and Accountable Public Service : 2015 .

10. Nigussa F. Can Citizens ' Charters Succeed in Ethiopia 2013;14:2-4. Available from: https://addisfortune.net

11. Habib M, Abera AK. Assessment of Citizens ' Charter Implementation Status in ase of o Selected Regional State Oromia Region of Ethiopia: The Case Bureaus us. Int $J$ African Asian Stud. 2016;28:1-10.

12. Jimma Universtiy. Jimma university citizens' charter standrad. Jimma University 2017. p. 133.

13. Rab A. Challenges and Prospects of Implementing Citizen Charter: A Study of Union Parishad in Bangladesh. Res Humanit Soc Sci. 2017;7(3):1-8.

14. Gurung G, Gauld R, Hill PC, Derrett S. Citizen's Charter in a primary health-care setting of Nepal: An accountability tool or a "mere wall poster"? Heal Expect [Internet]. 2017;21(1):149-58. 